\title{
WHOLE-BODY VIBRATION TRAINING PROTOCOLS IN OBESE INDIVIDUALS: A SYSTEMATIC REVIEW
}

\author{
PROTOCOLOS DE TREINAMENTO DEVIBRAÇÃO DE CORPO INTEIRO EM OBESOS: \\ UMAREVISÃOSISTEMÁTICA
}

PROTOCOLOS DE ENTRENAMIENTO DE VIBRACIÓN DE CUERPO ENTERO EN OBESOS: UNAREVISIÓN SISTEMÁTICA

Fábio Antônio Tenório de Melo (Physical Education Professional) Gislane Ferreira de Melo' (Physical Education Professional) Severino Leão de Albuquerque Neto ${ }^{1}$

(Physical Education Professional) Rogério Wagner da Silva' (Physical Education Professional) Nanci Maria de França (Physical Education Professional) Amanda Alves da Silva' (Physical Education Professional) Carlos Ernesto Santos Ferreira ${ }^{2}$ (Physical Education Professional)

1. Universidade Católica de Brasília (UCB/DF), Laboratório de Estudos da Força (LABEF/UCB/DF), Brasília, DF, Brazil.

2. Universidade Católica de Brasília (UCB/DF), Laboratório de Avaliação Física e Treinamento (LAFIT/UCB), Brasília, DF, Brazil.

\section{Correspondence:}

Fábio Antônio Tenório de Melo. Department of Physical Education, Escola da Saúde e Medicina, Universidade Católica de Brasília (UCB/DF), QS 7 Área Lote 1, EPCT, Águas Claras, Brasília, DF, Brazil. 71.966.700. ftenorio@ucb.br

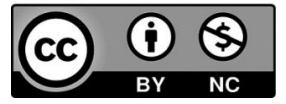

\section{ABSTRACT}

Obesity is a chronic degenerative disease. Whole-body vibration (WBV) devices make it possible to control the intensity of exercises through their variables: frequency, amplitude and vibration time, thus enabling interventions in these populations. The objective of this study was to review the applications, protocols and results of WBV devices in obese individuals. A systematic literature review was conducted using the descriptors and terms verified in DeCS (LILACS and SCIELO) and MeSH (PubMED). Of the thirteen studies selected, seven used an experimental and six a quasi-experimental methodological design. Eleven studies analyzed chronic responses and two studies acute responses to WBV training. Frequency values ranged between 30 and $35 \mathrm{~Hz}$, amplitude was around $2 \mathrm{~mm}$, and in terms of intensity, most of the training protocols used a gradual increase in WBV throughout the intervention. Eight studies added dynamic exercises and extra loads to the WBV. The mean total WBV exposure time varied around $20^{\prime}$ distributed in 1 or 2 series, with vibration times of $30^{\prime \prime}$ to $60^{\prime \prime}$ and the same rest time. The mean frequency of interventions was around 2 to 3 times a week, with a mean intervention time of 10 months. The main results include: decrease in body weight and improvement in the physiological variables of oxygen absorption, bone mineral density and arterial profile, indicating that WBV can be a safe tool in the fight against obesity and its implications. Level of Evidence II. Systematic Review of Level II Studies.

Keywords: Vibration of whole body; Vibratory platform; Obesity.

\section{RESUMO}

A obesidade é uma doença crônica degenerativa. Os aparelhos de vibração de corpo inteiro (VCI) permitem o controle da intensidade dos exercícios através das suas variáveis: frequência, amplitude e tempo de vibração, possibilitando intervenções nessas populações. O objetivo do presente estudo foi realizar uma revisão sobre as aplicações, protocolos e resultados dos aparelhos de VCl em indivíduos obesos. Realizou-se uma revisão sistemática da literatura utilizando os descritores e termos verificados no DeCS (LILACS e SCIELO) e no MeSH (PUbMED). Dos 13 estudos selecionados, sete utilizaram o delineamento metodológico do tipo experimental e seis do tipo quase-experimental. Onze estudos analisaram as respostas crônicas e dois as respostas agudas ao treinamento com VCl. Os valores de frequência variaram entre 30 e $35 \mathrm{~Hz}$, a amplitude, em torno de $2 \mathrm{~mm}$, e, em relação à intensidade, a maioria dos protocolos de treinamento utilizara o aumento gradativo da VCl ao longo da intervenção. Oito estudos adicionaram exercícios dinâmicos e cargas extras à VCl. O tempo médio de exposição total à VCl variou em torno de 20' distribuídos em 1 ou 2 séries, com tempos de 30" a 60" de vibração pelo mesmo tempo de descanso. A frequência média das intervenções foi em torno de 2 a 3 vezes por semana, com tempo médio de 10 meses de intervenção. Entre os principais resultados destacam-se: redução do peso corporal e melhoria nas variáveis fisiológicas da absorção de oxigênio, da densidade mineral óssea e do perfil arterial, indicando que a VCl pode ser uma ferramenta segura no combate à obesidade e suas implicações. Nível de Evidência II. Revisão Sistemática de Estudos de Nível II.

Descritores: Vibração de corpo inteiro; Plataforma vibratória; Obesidade.

\section{RESUMEN}

La obesidad es una enfermedad crónica degenerativa. Los aparatos de vibración de cuerpo entero (VCE) permiten el control de la intensidad de los ejercicios por medio de sus variables: frecuencia, amplitud y tiempo de vibración, posibilitando intervenciones en estas poblaciones. El objetivo del presente estudio fue realizar una revisión sobre las aplicaciones, protocolos y resultados de los aparatos de VCE en individuos obesos. Se realizó una revisión sistemática de la literatura utilizando los descriptores y términos verificados en el DeCS (LILACS y SCIELO) y en el MeSH (PUbMED). De los trece estudios seleccionados, siete utilizaron delineamiento metodológico del tipo experimental y seis del tipo cuasi experimental. Once estudios analizaron las respuestas crónicas y dos las respuestas agudas al entrenamiento con VCE. Los valores de frecuencia variaron entre 30 y $35 \mathrm{~Hz}$, la a mplitud, alrededor de $2 \mathrm{~mm}$, y con relación a la intensidad, la mayoría de los protocolos de entrenamiento utilizó el aumento gradual de la VCE, a lo largo de la intervención. Ocho estudios agregaron ejercicios dinámicos y cargas extra a la VCE. El tiempo promedio de exposición total a la VCE varió en torno a 20 'distribuidos en una o dos series, con tiempos de 30" a 60" de vibración por el mismo tiempo de descanso. 
La frecuencia promedio de las intervenciones fue alrededor de dos a tres veces por semana, con tiempo promedio de 10 meses de intervención. Entre los principales resultados se destacan: reducción del peso corporal y mejora en las variables fisiológicas de la absorción de oxígeno, de la densidad mineral ósea y del perfil arterial, indicando que la VCE puede ser una herramienta segura en el combate a la obesidad y sus implicaciones. Nivel de evidencia II. Revisión Sistemática de Estudios de Nivel II.

Descriptores: Vibración de cuerpo entero; Plataforma vibratoria; Obesidad.

\section{INTRODUCTION}

Obesity is the excessive accumulation of body fat and is considered a chronic and progressive disease because it is associated with several comorbidities. The main cause of obesity is a sedentary lifestyle, but it can be associated with factors, such as eating disorders as well as genetic, endocrine, metabolic, psychological, and sociocultural issues. ${ }^{1-4}$

Evidences have confirmed that the best strategies for reducing body weight and, consequently, mitigating the negative actions of obesity are behavioral changes and dietary restrictions; both strategies are associated with physical exercise. ${ }^{2,5}$ Research has demonstrated the benefits of losing body fat among obese individuals. However, adherence to any type of exercise is still low at 30\%.6-8 The most cited causes of obesity include time restraints, a lack of motivation, high financial cost, and displeasure. ${ }^{9,10}$

New methodologies and equipment are emerging in an attempt to provide the public with new options for physical exercises that are less time-consuming and exposure, and offer improved results. Whole body vibration (WBV) devices, such as the vibratory platforms (VPs), stand out among the new options. These devices have led to an increase in research since their conception, seeking to identify their actions and effects in different populations. ${ }^{11-32}$

Exposure to vibration using a VP occurs through the contact of distal ends of the body segments. The effect produced from this contact can spread along many tissues before reaching the muscles and bones. ${ }^{33,34}$ The more the muscle and bone system is activated during the vibration process, the better the physiological responses provided to its practitioners. ${ }^{35}$

Platforms currently available in the market allow one to select a wide range of variables that can be manipulated to maximize the final effects. These variables are amplitude ( $\mathrm{mm}$; from $2 \mathrm{~mm}$ to $10 \mathrm{~mm}$ ), frequency $(\mathrm{Hz}$; from $12 \mathrm{~Hz}$ to $50 \mathrm{~Hz}$ ), and exposure time (from 30 seconds to 9 uninterrupted minutes). In addition to the combined aforementioned variables, it is possible to periodize training, correlating the number of sets performed in a session with weekly training frequency, and the duration of each series or the total program time. ${ }^{36,37}$

VPs offer several protocol possibilities. However, the combinations that produce the best effects when applied to obese populations are still unknown. Therefore, the objective of this systematic review was to investigate the most commonly used protocols for WBV training in obese individuals.

\section{METHODS}

\section{Systematic review}

The theoretical assumptions proposed by the Cochrane collaboration manual were used in this systematic review. ${ }^{38}$ All descriptors and terms were checked in the DeCS server (LILACS and SCIELO) and MeSH (PubMED).

The following inclusion criteria were considered: a. Studies published in indexed scientific journals from 2000 to 2017 in any language. b. Original studies linked to journals indexed in the selected databases that investigated the effects of WBV on obese individuals as the main or secondary objective

The exclusion criteria were:

a. Incomplete studies (no results).

b. Studies without identification of the authors or journal of publication. c. Studies in which vibration was not caused by a vibrating platform.

d. Repeated studies, or studies meeting part of the inclusion criteria without presenting the vibration results separately, or another population were excluded, for preventing the main objective of this study.

Searches in the electronic databases were performed from June 26 to August 16, 2017, following the methodological recommendations for the systematic reviews. ${ }^{39}$

This review is part of a project approved by CNPq through the Public Notice number 446400/2014.

\section{RESULTS}

The descriptors used in the LILACS database were "Plataforma vibratória,"'Exercício vibratório,"“"Treinamento vibratório," 'Vibração de corpo inteiro," "Vibration of whole body," "Vibratory plataforma," "Vibración de cuerpo entero," "obesidade," "indivíduos obesos," "adultos," and "adultos obesos," which were combined with the Boolean operators or/and. Sixteen potentially eligible articles were found in this database. After reading the titles and, in some cases, the abstracts, it was found that none of the publications dealt with full body vibration training for obese population as the main or secondary objective.

In the Scielo electronic database, the descriptors were used in various combinations, with the same Boolean operators already mentioned. Once again, no study relating the aspects of vibration training to obese populations was found.

The PubMed database was searched using the descriptors "Vibrating platform"(104), "Vibratory training"(154), "Vibrating exercise"(71), "Whole body vibration (1820),"'Obesity," 'Obese individuals," and "Obese adults," which were also combined with Boolean operators or/and.

The searches resulted in 118 potentially eligible publications. After reading the titles and, in some cases, the abstracts that showed potential, 88 were excluded because they did not meet the inclusion criteria adopted. After reading in full the 30 pre-selected studies, 17 were excluded. Hence, 13 studies were selected in the PubMed database for this systematic review, in accordance with the Figure 1.

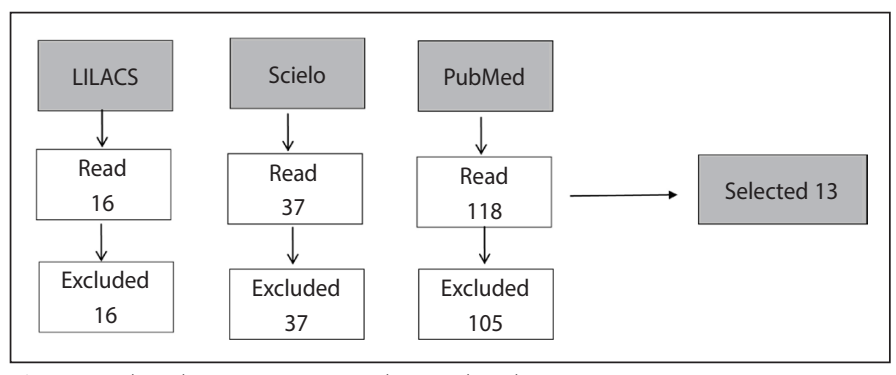

Figure 1. Flowchart summarizing the article selection. 
Table 1 shows the results of the 13 articles selected for evaluation, along with the following variables: authors, publication year, objectives, sample, instruments and procedures, and results and conclusions.

\section{DISCUSSION}

Table 1 lists the summaries of the main revised studies that used VPs as an exercise intervention for obese populations.

Most WBV studies with obese individuals were performed with female participants, with BMl ranging from $25 \mathrm{gg} / \mathrm{m}^{2}$ to over $40 \mathrm{~kg} / \mathrm{m}^{2}$, aged between 18 and 68 years. The most common age group was individuals aged from 30 to 46 years. ${ }^{40,41,43,44,47}$

Most studies used an experimental methodological design with control group and sampled mostly sedentary individuals. Six of the 13 surveys used a quasi-experimental design with no control group. Two surveys ${ }^{40,46}$ used acute vibration training responses and the rest, training interval ranging from 4 to 12 weeks. ${ }^{41-45,47-52}$

The first two findings of this review were reports from Vissers et al. ${ }^{40.41}$ The first aimed to closely examine and compare improvement in oxygen uptake levels $\left(\mathrm{O}_{2}\right)$ during resistance exercise (RE) sessions by adding IVC. In the second study, now a chronic context, vibratory exercises were associated with aerobic exercises (AE), in an attempt to identify if the results could positively affect body weight (BW), body composition (BC), $\mathrm{BMI}$, heart rate (HR), and factors linked to metabolic syndrome (MS). Vissers et al. ${ }^{40}$ showed that carbon dioxide production $\left(\mathrm{CO}_{2}\right)$ and absorption of oxygen $\left(\mathrm{O}_{2}\right)$ were significantly higher in the group that performed the $\mathrm{RE}$, in addition to the WBV, but did not show differences when the two groups were compared. The subjective perception of exertion (SPE) was also used to check the intensity of the exercises and showed greater evidence in the RE that was added to the vibration.

The second study ${ }^{41}$ was performed in a chronic way, with a sample of 61 sedentary women forming three groups: G1 (diet only), G2 (diet with EA exercises), G3 (diet in addition to WBV), and G4 corresponding to the control group ( $n=21$; no diet or exercise). The actions were followed by a six-month intervention, followed by another six months without intervention, amounting to a total of 12 months. The variables analyzed were BMI, BC, tomography, blood pressure (BP), blood count, resting $E C G$, and pulmonary function. The results showed that associating AE and WBV with a low-calorie diet may help maintain weight loss, especially visceral adipose tissue (VAT), as this marker plays a central role in metabolic syndrome. Weight loss in the 12-month interval was more

Table 1. Summary of studies selected for review.

\begin{tabular}{|c|c|c|c|c|c|}
\hline Authors/Year & Objectives & Sample & Instruments & Results & Conclusion \\
\hline $\begin{array}{c}\text { Vissers, D.; } \\
\text { Baeyens, J.P.; } \\
\text { Truijen, S.; et al. }{ }^{40} \\
\end{array}$ & $\begin{array}{c}\text { Compare } \mathrm{O} 2 \text { consumption } \\
\text { in overweight women }\end{array}$ & $\begin{array}{c}20 \text { women } \\
\geq 30 \mathrm{~kg} / \mathrm{m}^{2} \pm 37 \text { years }\end{array}$ & $\begin{array}{c}\text { BMI, Skinfold (4-fold), VO2 } \\
\text { and VCO2, FC (portable gas } \\
\text { analyzer), BORG scale }\end{array}$ & $\begin{array}{l}\mathrm{CO}_{2} \text {, relative absorption of } \mathrm{O}_{2} \\
\text { and } \mathrm{HR} \text { were } \uparrow \text { on vibration }\end{array}$ & $\begin{array}{l}\text { 个 O2 absorption with WBV. The } \\
\text { physiological pathways behind } \\
\text { these results are still uncertain. }\end{array}$ \\
\hline $\begin{array}{l}\text { Vissers. D.; Na, V.; } \\
\text { Ilse, M.; et al. }{ }^{41}\end{array}$ & WBV and jogging & $\begin{array}{c}\mathrm{N}=61 \text { overweight } \\
\text { and obese. }\end{array}$ & $\begin{array}{l}\text { BMI, WC, Co. Cpor bio } \\
\text { impedance, tomography, P.A; } \\
\text { lipids and glucose, insulin, } \\
\text { resting ECG, spirometry, }\end{array}$ & $\begin{array}{l}\text { Body weight } \downarrow \text { in the } 3 \\
\text { groups. VAT }>\text { in the vibration } \\
\text { group. Vibration group } \\
\text { lost }+10 \% \text { of the PC. }\end{array}$ & $\begin{array}{l}\text { Both exercises combined with } \\
\text { a low-calorie diet, } \downarrow 5-10 \% \text { of } \\
\text { CP in the first } 6 \text { months and are } \\
\text { sustained for another } 6 \text { months. }\end{array}$ \\
\hline Song et al. ${ }^{42}$ & $\begin{array}{c}\text { Examine Effects of WBV } \\
\text { on Weight Change, Waist } \\
\text { Circumference (WC) }\end{array}$ & $\begin{array}{c}\mathrm{n}=15 \text { Obese Menopausal } \\
\text { Women } \leq 50 \text { years } \\
B M I \geq 25\end{array}$ & $\begin{array}{l}\text { Weight, WC, BMI, PA., } \\
\text { Bio impedance }\end{array}$ & \begin{tabular}{|c|} 
No different vibrations were \\
applied. There was no control \\
over diet and exercise at 8 weeks.
\end{tabular} & $\begin{array}{l}\text { Produced small reductions in } \\
\text { the } \mathrm{CP} \text {, central obesity; } \downarrow \mathrm{MM}\end{array}$ \\
\hline $\begin{array}{c}\text { Miyake, A.; } \\
\text { Maeda, S.; Choi, } \\
\text { Y.; et al. }{ }^{43}\end{array}$ & WBV + diet and EA & $\begin{array}{l}\mathrm{N}=12 \text { overweight } \\
\text { and obese women } \pm \\
42 \text { years old, BMl: } 32\end{array}$ & $\begin{array}{l}\text { PWV, P.A, Plasma Concentration, } \\
\text { Blood Analysis, Maximum } \\
\text { O2 Capitation, C.C (Dexa). }\end{array}$ & $\begin{array}{l}\downarrow \text { : Weight, BMI, WC,\% M. G; M.C. } \\
\text { M. and } \uparrow \text { VO2. Total cholesterol, } \\
\quad \text { triglycerides } \downarrow 12 \text { weeks. }\end{array}$ & $\begin{array}{c}\downarrow \text { R.A without reducing } \\
\text { the } \% \text { M.M.C. } \uparrow \text { PTX3 } \\
\text { concentrations. Failed to } \\
\text { confirm WBV actions alone }\end{array}$ \\
\hline $\begin{array}{l}\text { Wilms, B.; Frick, J.; } \\
\text { Ernst, B.; et al. }{ }^{44}\end{array}$ & Effects of WBV Added to TF & $\begin{array}{c}\mathrm{N}=14 \text { obese women } \\
\text { BMI: } 37.4 \pm 1.3 ; \text { Age: } \\
43.1 \pm 3.5 \text { years }\end{array}$ & $\begin{array}{c}\text { BC, WC, Phase angle, Resting } \\
\text { energy expenditure }\end{array}$ & $\begin{array}{l}\text { There was no change in P.C. } \\
\downarrow W C \text {. Improvement in the } \\
\text { WBV group in relation to phase } \\
\text { angle. } \downarrow \text { of MS in both groups. }\end{array}$ & $\begin{array}{l}\text { Group with exercise and WBV } \\
\text { improved the phase angle. There } \\
\text { was no } \downarrow \text { from Co. C, RES in } \\
\text { the VCI group. There was no } \\
\text { consensus on what frequency, } \\
\text { amplitude and duration to use. }\end{array}$ \\
\hline $\begin{array}{l}\text { Figueroa, A.; } \\
\text { Gil, R.; Wong, } \\
\text { A.; et al. }{ }^{45}\end{array}$ & $\begin{array}{l}\text { WBV in arterial function, } \\
\text { autonomic and strength }\end{array}$ & $\begin{array}{l}\mathrm{N}=10 \text { women }(18-35 \\
\text { years), } \mathrm{BMI}>25 \mathrm{~kg} / \mathrm{m}^{2}\end{array}$ & PWV, P.A, (ECG),1RM & $\begin{array}{c}\downarrow \downarrow \text { systemic arterial stiffness, } \\
\text { hemodynamic part, HR variability } \\
\text { and muscle strength. Acute } \\
\text { changes in P.A., PWV and PWR. } \\
\end{array}$ & $\begin{array}{c}6 \text { weeks of vibration } \\
\text { training were effective to } \\
\downarrow \text { PWR, magnitude and } \\
\text { autonomic requlation. }\end{array}$ \\
\hline $\begin{array}{c}\text { Giunta, } M_{. ;} \\
\text {Cardinale, } M_{. ;} \\
\text {Agosti, F.; et al. }{ }^{46} \\
\end{array}$ & WBV in $\mathrm{GH}$ responses & $\begin{array}{c}\mathrm{N}=7 \text { obese women, } \\
18 \text { and } 30 \text { years of age. } \\
35-44 \mathrm{~kg} / \mathrm{m}^{2}, \mathrm{BMl}\end{array}$ & $\begin{array}{l}\text { Blood ( } 5 \mathrm{ml}) \text {, taken before } \\
\text { and immediately after. }\end{array}$ & \begin{tabular}{|c|} 
WBV alone and WBV+ \\
external load caused $\uparrow$ at GH \\
levels. $\uparrow$ on lactate levels.
\end{tabular} & $\begin{array}{c}\text { Vibration alone stimulates } \\
\text { GH release and severe } \\
\text { lactate production. }\end{array}$ \\
\hline $\begin{array}{c}\text { Milanese, C.; } \\
\text { Piscitelli, F.; Zenti, } \\
\text { M.G, et al. }{ }^{47} \\
\end{array}$ & $\begin{array}{l}\text { WBV in Anthropometry, } \\
\text { C.C. and strength }\end{array}$ & $\begin{array}{l}N=50 \text { women } \\
\text { Age: } 46.6 \pm 7.8 \\
\text { BMl: } 35.1 \pm 3.55\end{array}$ & $\begin{array}{l}\text { Weight, WC, SF, LBM and FM } \\
\text { and DMO (DEXA), FM (1RM) }\end{array}$ & $\begin{array}{c}\downarrow \text { BMI, Skin folds, BC, WC, } \\
\text { positive effects on BMD. } \\
10 \text { weeks of training } \\
\end{array}$ & $\begin{array}{l}\text { WBV represents a useful addition } \\
\text { to exercise habits for the obese } \\
\text { audience. Changes in } \mathrm{BC} \text { and } \mathrm{FM} \text {. }\end{array}$ \\
\hline Bellia, et al. ${ }^{48}$ & $\begin{array}{l}\text { WBV + diet on } \\
\text { insulin sensitivity and } \\
\text { glucose tolerance. }\end{array}$ & $\begin{array}{c}\mathrm{N}=29 \text { women, } \mathrm{BMI}> \\
\text { aged from } 40 \pm 42 \text { years }\end{array}$ & $\begin{array}{c}\text { PA, Weight, WV, IPAQ, BC, GCT, } \\
\% \text { G. and DMO (DEXA). }\end{array}$ & $\begin{array}{c}\text { WBV }+ \text { diet } \uparrow \text { insulin sensitivity } \\
\text { and glucose regulation. } \downarrow \\
\text { TBF }>\text { at WBV. Adiponectin } \\
\uparrow \text { in the WBV group. } \\
\end{array}$ & $\begin{array}{l}\text { WBV + low-calorie diet } \\
\text { may improve metabolic } \\
\text { characteristics and WC. }\end{array}$ \\
\hline Zaki $^{49}$ & $\begin{array}{l}\text { WBV and RT, in } \\
\text { obese individuals }\end{array}$ & $\begin{array}{l}\mathrm{n}=80 \text { women. } 50 \\
\text { to } 68 \text { years of age. } \\
\text { BMl: } 30-36 \mathrm{Kg} / \mathrm{m}^{2}\end{array}$ & DEXA, BMI, WC. & $\begin{array}{l}\text { Improvements in BMD } \\
\text { for both WBV and T.R. }\end{array}$ & $\begin{array}{l}\text { BMI and WHR } \downarrow \text { in both } \\
\text { groups as well as in BMD. }\end{array}$ \\
\hline $\begin{array}{l}\text { Oh, et al. }{ }^{50} \\
\text { They train. } \\
\text { acceleration }\end{array}$ & $\begin{array}{l}\text { WBV and non-alcoholic } \\
\text { fatty liver disease in } \\
\text { physical, hepatic, and } \\
\text { metabolic functions. }\end{array}$ & $\begin{array}{c}\mathrm{N}=18 \text { participants: } \\
4 \text { men } \\
14 \text { women }\end{array}$ & $\begin{array}{l}\text { VO2 and VCO2 and Respiratory } \\
\text { Exchange, PC and BC., Blood } \\
\text { analysis, Liver Stiffness, Fat } \\
\text { in liver and muscles, Muscle } \\
\text { Strength and QOL (SF-36). }\end{array}$ & $\begin{array}{c}\text { Did not show } \uparrow \text { RES after } 12 \\
\text { weeks. } \downarrow \text { PC, BMI, MG, and } \\
\text { visceral fat area. No change } \\
\text { actions in MCM. } \uparrow \text { strength, } \uparrow \\
\text { inflammatory proteins and QOL. }\end{array}$ & $\begin{array}{l}\text { WBV } \uparrow \text { physical function by } \\
\text { repairing hepatic steatosis levels. }\end{array}$ \\
\hline $\begin{array}{l}\text { Nam, S.; Sunoo, } \\
\text { S.; Park, H.; } \\
\text { Moon, } \mathrm{H}^{51}\end{array}$ & $\begin{array}{l}\text { Diet + WBV, with diet } \\
\text { alone combined with EA } \\
\text { in BC and obese BMD. }\end{array}$ & $\begin{array}{c}\mathrm{N}=45 \text { women agreed } \\
\text { from } 30 \text { to } 55 \text { years. } \\
\text { BMI }>30 \mathrm{Kg} / \mathrm{m}^{2} .\end{array}$ & BMI, SF, PC, LBM, FM, DMO. & $\begin{array}{l}\text { PC and FM } \downarrow \text { in the } 3 \\
\text { groups. Skin folds, WC. and } \\
\text { WHR, without differences } \\
\text { between groups. } \uparrow \text { DMO }\end{array}$ & $\begin{array}{c}\text { WBV + calorie restricted diet } \\
\text { is as effective as combining } \\
\text { diet and aerobic exercise. }\end{array}$ \\
\hline $\begin{array}{c}\text { Alvarez-Alvarado } \\
\text { et al. }{ }^{52}\end{array}$ & $\begin{array}{l}\text { WBV in arterial } \\
\text { function and FM. }\end{array}$ & $\begin{array}{l}\mathrm{N}=42 \text { women aged } \\
\text { from } 18 \text { to } 25 \text { years. } \\
\text { BMl: } 27-40 \mathrm{~kg} / \mathrm{m}^{2} .\end{array}$ & $\begin{array}{l}\text { BMI, WC, body composition } \\
\text { (DEXA), RA. P.A, 1RM (Leg Press) }\end{array}$ & $\begin{array}{l}\text { M.I. strength } \uparrow \mathrm{VCl} \text {. There } \\
\text { were no significant changes in } \\
\text { brachial P.A in either group. }\end{array}$ & $\begin{array}{c}\text { After } 6 \text { weeks, the WBV dynamic } \\
\text { group } \downarrow \text { RAS and aortic, PA } \\
\text { and } \mathrm{RO}, \uparrow \text { M.l. strength }\end{array}$ \\
\hline
\end{tabular}

个 Increased, $\downarrow$ Decreased, VAT: Visceral Adipose Tissue; > Greater than; < Less than; > Greater or Equal; BW: Body Weight; WC: Waist Circumference; PWV: Pulse Wave Velocity; LBM: Lean Body Mass; FM: Fat Mass; AS:Ateria

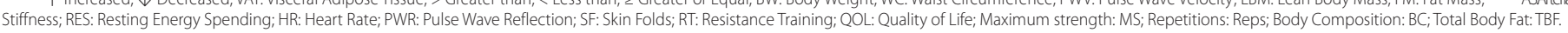


effective in the AE and WBV groups than in the diet-only group. The diet-associated Vibration group was the only one to succeed in losing more than $10 \%$ of body weight at 6 months with maintenance up to 12 months. This led the authors to conclude that aerobic exercise that is associated with WBV in chronic form, in addition to a dietary control (low calorie diet), assists in reducing fat weight.

Song et al. ${ }^{42}$ found similar unpublished results in relation to reduced central obesity and waist circumference (WC) in healthy obese women aged $\leq 50$ and with $\mathrm{BMI} \geq 25 \mathrm{~kg} / \mathrm{m}^{2}$. However, they did not corroborate the findings of Yoo et al. ${ }^{53}$ who used the same experimental design but found no effective results with WBV.

Other studies in this review ${ }^{40,41,42}$ also focused on the effects ofWBV on BMI, BC, and body mass $44,47,48,51,52$; the results were positive when WBV was performed alone $40,42,47,50-52$ or associated with AE and diet $40,43,48,51$. The benefits reported were, among others, improved insulin resistance, glucose regulation, decreased systemic arterial stiffness, hemodynamic actions, heart rate, and in parameters related to strength.

In associating vibration with strength training (ST), the results were also positive. Giunta et $a l .{ }^{46}$ associated dynamic exercises and external overload, using a weighted vest, with WBV; the results indicated significant increases in GH and lactate levels. Zaki ${ }^{48}$ compared ST and WBV in an obese group; the effects on BMI, RCQ, and bone mineral density (BMD) did not show significant differences among the groups.

Figueroa et al. ${ }^{54}$ and Olson et al. ${ }^{55}$ also presented the effects of associating WBV with ST, which were satisfactory regarding physiological issues. They consolidated this type of training as a safe tool for overweight and obese populations. When ST is performed alone and with high intensity, there are possible adverse chronic effects in relation to wave speed, pulse, arterial stiffness, ${ }^{56}$ and pathologies to which these patients present a predisposition.

In this sense, WBV exercises bring favorable consequences. Miyake et al. ${ }^{43}$, Figueroa et al. $^{45}$, and Alvarez-Alvarado et al. ${ }^{52}$ reported positive results in the reduction of systemic and aortic arterial stiffness (AAS), wave reflex (WR), magnitude and autonomic regulation, and strength parameters, which specifically corroborated the findings associated with strength reported by Milanese et al. ${ }^{47}$

Alvarez-Alvarado et al. ${ }^{52}$, which was the most recent study presented in this review, sought to answer questions related to AAS using WBV as an intervention; they reported positive results, which Otsuki et al. ${ }^{57}$ corroborated. Pulse pressure is defined as the difference between systolic and diastolic pressure. It is used indirectly as an AAS marker and is a predictor of risk for myocardial infarction and heart failure, conditions that may be a consequence of obesity. ${ }^{58,59}$

Wilms et al. ${ }^{44}$ was the only study within this review that investigated the phase angle by bioelectrical impedance. The results showed an increased angle in the vibratory exercises. In obese individuals, the phase angle correlated negatively with BMI. ${ }^{60}$

Following the same parameters, Milanese et al. ${ }^{47}$ evaluated another combination of vibratory exercises. They associated WBV with radiofrequency through an electric wave emission device using adhesives placed on the distal regions of the body and trunk, with values of $75 \%$ of the maximum power of the device. However, the results showed no difference from the vibration-only group, such that the researchers decided to exclude radiofrequency and set up a single WBV-only group.

In turn, Oh et al..$^{50}$ evaluated WBV results in obese patients with non-alcoholic Fatty Liver Disease by analyzing physical condition, BC, liver and metabolic function, liver fat content, skeletal muscle, and quality of life in relation to health. The results found were that WBV reduced body adiposity, showing a significant reduction in liver fat and lipid content, and on the occurrence of abnormalities shown in results of liver function tests.

Finally, the findings of this review also analyzed BMD $47,49,51$ and bone mineral contents (BMC) $)^{51}$ in obese patients submitted to WBV. The results were positive, showing an increase and maintenance of this variable. These implications are corroborated by Verschueren et al.,22 who used vibration in 70 postmenopausal women three days a week for six months and reported significant increases in BMD in the hip region.

Table 2 describes the protocols used in all articles investigated.

In this review, related studies used vibration devices of different brands, models, and origins. Vissers et al. ${ }^{40}$ used Galileo 2000 platforms of the Novotec $\mathrm{GmbH}$ brand made in Germany. Vissers et al., ${ }^{41}$ Miyake et al. ${ }^{43}$ Figueroa et al., ${ }^{45}$ Oh et al., ${ }^{50}$ and Alvarez-Alvarado et al. ${ }^{52}$ employed a Power Plate vibrating appliance model Pro5 and Pro6, made in North America. Song et al. ${ }^{42}$ and Nam et al. ${ }^{51}$ used the Korean Medieos platform and model EOS 6600. Wilms et al. ${ }^{44}$ used a Belgian vibratory platform of the FITVIBE brand ${ }^{\circ}$, Excel Pro model, as a research instrument. Giunta et al. ${ }^{46}$ conducted their studies in the Italian population, using an Italian vibration device of the brand NEVISYS H1 ${ }^{\circ}$ and model RME. Milanese et al. ${ }^{47}$ also used an Italian-made platform but with a different make and model, specifically Bioplate RF, BIOS. Another Italian study used a Nemes Perform ${ }^{73}$ vibration appliance. Finally, Zaki ${ }^{49}$ used a Chinese-made OMA 701A model platform in her research.

The devices used in the studies of this review were vibratory platforms and had protocols that can be manipulated using variables, such as frequency, amplitude, vibration intensity, and vibration duration.

Regarding the protocols used in the studies of this review, the most commonly used vibration frequency was between $30 \mathrm{~Hz}$ and $35 \mathrm{~Hz}$. Of these, some maintained a single frequency of vibration without changes, while for others, such as, Vissers et al., Miyake et al., Figueroa et al., Oh et al., and Alvarez-Alvarado et al., this variable gradually increased. 40,41,43-48,50,52

The lowest frequencies were used by Song et al. ${ }^{42}$ and Zaki ${ }^{49}$ at 20 $\mathrm{Hz}$ and $16 \mathrm{~Hz}$, respectively. Nam et al. ${ }^{51}$ reached $30-35 \mathrm{~Hz}$ frequency in vibration; however, they began their studies around $16 \mathrm{~Hz}$. Figueroa et al. ${ }^{45}$ began their studies with $25 \mathrm{~Hz}$. The highest intensities were used by Vissers et al., ${ }^{41}$ with values up to $40 \mathrm{~Hz}$, and Milanese et al. ${ }^{47}$ who began interventions with frequency values of $40 \mathrm{~Hz}$ reaching up to 60 $\mathrm{Hz}$. Finally, Oh et al. ${ }^{50}$ applied values up to $40 \mathrm{~Hz}$.

Some studies did not identify or clarify the amplitude used. ${ }^{41,46,49,50,52}$ Giunta et al. ${ }^{46}$ also concluded acceleration. The rest of the studies used amplitude values ranging from $1 \mathrm{~mm}$ to $6.8 \mathrm{~mm}$, with a prevailing value of $2 \mathrm{~mm}^{42-45.48}$ The first study of this review ${ }^{40}$ was the only one to use a $4 \mathrm{~mm}$ amplitude. All studies also used the same amplitude values from start to finish. Only Figueroa et al. ${ }^{45}$ began their intervention with an amplitude of $1 \mathrm{~mm}$, increasing to $2 \mathrm{~mm}$. A similar procedure was adopted by Milanese et al., ${ }^{47}$ who began by applying amplitudes of 2 $\mathrm{mm}$, increasing to $5 \mathrm{~mm}$. Nam et al. ${ }^{51}$ used the highest amplitude values of this review (6.8 mm), as a consequence of using a different VP model.

Some of the studies reviewed did not report vibration intensity values and did not elucidate why. Possibly, the vibration devices did not make this variable available or the researchers themselves did not choose to use it. ${ }^{44-49,51}$

Some studies began and maintained the same vibration times, alternating with resting periods between sets. Song et al. ${ }^{42}$ began with a sample vibrating for $10^{\prime}$ in a single series. This is similar to Nam et al., ${ }^{51}$ who used 11', amounting to $33^{\prime}$ in 3 sets with 5 ' rest.

In Vissers et al., ${ }^{40}$ the same group performed exercises without WBV, rested for 10 minutes, and performed the same exercises with WBV. Each action was performed for 3 minutes in each single series exercise. Giunta et al. ${ }^{46}$ performed an action with 2 groups, where $\mathrm{G} 1$ performed the WBV 
Table 2. Summary of all WBV protocols used in this review.

\begin{tabular}{|c|c|c|c|c|c|c|c|c|c|}
\hline Authors & Frequ. & Amplit. & Intens. & Time & Series & $\begin{array}{c}\text { Types of } \\
\text { Exercises }\end{array}$ & T. Total & $\begin{array}{c}\text { Times per } \\
\text { week }\end{array}$ & Results \\
\hline $\begin{array}{l}\text { vissers } \\
\text { et al. }{ }^{40}\end{array}$ & $35 \mathrm{~Hz}$ & $4 \mathrm{~mm}$ & High & $\begin{array}{c}3^{\prime} \\
10^{\prime} \text { Rest between } \\
\text { exercises }\end{array}$ & $1 x$ & $\begin{array}{c}3 \text { ex. WBV } \\
3 \text { ex. } / \text { WBV } \\
\text { Dyn. }\end{array}$ & $\begin{array}{c}3^{\prime} \\
\text { acute }\end{array}$ & $1 x$ & $\begin{array}{l}\uparrow \mathrm{O}_{2} \text { absorption due } \\
\text { to WBV addition }\end{array}$ \\
\hline $\begin{array}{l}\text { Vissers } \\
\text { et al. }{ }^{41}\end{array}$ & $\begin{array}{c}30-35-40 \mathrm{~Hz} \\
\uparrow\end{array}$ & $\begin{array}{c}\text { Not } \\
\text { informed }\end{array}$ & $\begin{array}{c}\text { Low } / \text { High } \\
\uparrow\end{array}$ & $\begin{aligned} 30-45-60^{\prime \prime} & \\
& \uparrow \\
\text { Rest: }= & \text { Exercise }\end{aligned}$ & $1 x$ & $\begin{array}{l}\text { 1.2, 3rd } \\
\text { month: Est. } \\
\text { 4th,5th,6th } \\
\text { month: Dyn. }\end{array}$ & $\begin{array}{l}3 \text { months: } 11.9 \\
\text { 4th, 5th, and } \\
\text { 6th month: } 14.2^{\prime} \\
6 \text { months }\end{array}$ & $1 x$ & $\begin{array}{l}\text { The } 2 \text { exercises }+ \text { one diet, } \\
\downarrow 5 \%-10 \% \text { of CP in the first } \\
\text { six months and remained } \\
\text { for six more. WBV } \downarrow \text { to } \\
\text { C.C. and visceral fat. }\end{array}$ \\
\hline $\begin{array}{l}\text { Song } \\
\text { et al.42 }\end{array}$ & $20 \mathrm{~Hz}$ & $2 \mathrm{~mm}$ & Low & $10^{\prime}$ & $1 x$ & Est. & $\begin{array}{c}10^{\prime} \\
8 \text { weeks }\end{array}$ & $2 x$ & $\begin{array}{c}\text { small } \downarrow \text { in CP and } \\
\text { central obesity; } \\
\downarrow \text { MM }\end{array}$ \\
\hline $\begin{array}{l}\text { Miyake } \\
\text { et al. }{ }^{43}\end{array}$ & $\begin{array}{c}\text { 1st month: } 30 \mathrm{~Hz} \\
\text { 2nd month: } 35 \mathrm{~Hz} \\
\text { 3rd month: } 35 \mathrm{~Hz} \\
\uparrow\end{array}$ & $2 \mathrm{~mm}$ & Not informed & $\begin{array}{c}30^{\prime} \\
30^{\prime \prime} \text { Exercise Rest }\end{array}$ & $1 x$ & $\begin{array}{l}\text { 1st month: Est. } \\
\text { 2nd month: Est. } \\
\text { 3rd month: Dyn. }\end{array}$ & $\begin{array}{c}30^{\prime} \\
12 \text { weeks }\end{array}$ & $3 x$ & $\begin{array}{c}\downarrow \text { arterial stiffness } \\
\text { without } \downarrow \text { MM. } \uparrow \text { the } \\
\text { concentrations of PTX3 } \\
\text { resulting in a cardioprotective } \\
\text { effect and } \downarrow \text { PC }\end{array}$ \\
\hline $\begin{array}{l}\text { Wilms } \\
\text { et al. }{ }^{44}\end{array}$ & $30 \mathrm{~Hz}$ & $2 \mathrm{~mm}$ & Not informed & $\begin{array}{c}15-30^{\prime} \\
\uparrow \\
30 \text { "rest between } \\
\text { exercises }\end{array}$ & $1 x$ & $\begin{array}{c}\text { Aerobic + WBV } \\
\text { Est. }\end{array}$ & $\begin{array}{c}30^{\prime} \\
6 \text { weeks }\end{array}$ & $3 x$ & $\begin{array}{c}\text { Exercise + WBV improved the } \\
\text { phase angle. There was no } \downarrow \\
\text { from Co. C and GEO with WBV. } \\
\text { There was no consensus on } \\
\text { what frequency, amplitude, } \\
\text { and duration to use. }\end{array}$ \\
\hline $\begin{array}{l}\text { Figueroa } \\
\text { et al. }{ }^{45}\end{array}$ & $\begin{array}{c}25-30 \mathrm{~Hz} \\
\uparrow\end{array}$ & $1-2 \mathrm{~mm}$ & Not informed & $\begin{array}{c}30-60^{\prime \prime} \\
\uparrow \\
60^{\prime \prime}-30^{\prime \prime} \\
\downarrow\end{array}$ & $1 x$ & $\begin{array}{c}\text { Dyn. } \\
\text { Est. } \\
\text { Lower members }\end{array}$ & $\begin{array}{c}10^{\prime} \\
4 \text { weeks later }+ \\
4 \text { weeks }\end{array}$ & $3 x$ & $\begin{array}{c}6 \text { weeks of WBV } \downarrow \text { ROP, } \\
\text { magnitude and autonomic } \\
\text { regulation. Indicators of arterial } \\
\text { stiffness were } \downarrow \text { with the } \\
\text { intervention. WBV promoted } \\
\text { acute changes in P.A., VOP. }\end{array}$ \\
\hline $\begin{array}{l}\text { Giunta } \\
\text { et al. }{ }^{46}\end{array}$ & $30 \mathrm{~Hz}$ & $\begin{array}{l}\text { Acceler. } \\
2.85 \mathrm{~g}\end{array}$ & Not informed & $\begin{array}{c}\text { Est. } 10 \times 72 "-50 " \text { desc. } \\
\text { Dyn. } 10 x \\
50 \text { "rest }\end{array}$ & $\begin{array}{l}\text { Group } \\
1 \text { and } \\
2: 10 x\end{array}$ & $\begin{array}{c}\text { Est. } \\
\text { Dyn + External } \\
\text { load }\end{array}$ & $\begin{array}{l}19^{\prime} 30^{\prime \prime} \\
\text { acute }\end{array}$ & $1 x$ & $\begin{array}{c}\text { Vibration stimulates } \mathrm{GH} \text { and } \\
\text { lactate production without } \\
\text { additive effects when combined } \\
\text { with exercise with loads. } \\
\end{array}$ \\
\hline $\begin{array}{l}\text { Milanese } \\
\text { et al. }{ }^{47}\end{array}$ & $40-60 \mathrm{~Hz}$ & $2-5 \mathrm{~mm}$ & Not informed & $\begin{array}{c}14^{\prime} \\
5 \text { 'rest }\end{array}$ & $1 x$ & $\begin{array}{l}\text { WBV alone } \\
\text { WBV + RF } \\
\text { Est :30-60" }\end{array}$ & $\begin{array}{c}19^{\prime} \\
10 \text { weeks }\end{array}$ & $2 x$ & $\begin{array}{c}\text { WBV + RF by did not } \\
\text { present positive results. } \\
\text { WBV improved WC, } \\
\text { MS and BMD. } \\
\end{array}$ \\
\hline $\begin{array}{l}\text { Bellia } \\
\text { et al. }{ }^{48}\end{array}$ & $30 \mathrm{~Hz}$ & $2 \mathrm{~mm}$ & Not informed & $\begin{array}{l}1 \text { 'WBV with } \\
1 \text { 'rest }\end{array}$ & $1 x$ & Est. & $\begin{array}{c}20^{\prime} \\
8 \text { weeks }\end{array}$ & $3 \times(8 w k s)$. & $\begin{array}{l}\downarrow W C \text { in WBV, insulin } \\
\text { resistance and some } \\
\text { metabolic characteristics. }\end{array}$ \\
\hline Zaki49 & $16 \mathrm{~Hz}$ & $\begin{array}{c}\text { Not } \\
\text { informed }\end{array}$ & Not informed & $\begin{array}{l}\text { 1'WBV } \\
\text { 1'rest }\end{array}$ & \begin{tabular}{|c|} 
Evolved \\
from 3 to \\
10 series \\
\end{tabular} & $\begin{array}{l}1 \text { Group WBV } \\
1 \text { Group ST } \\
\text { Est. } \uparrow\end{array}$ & $\begin{array}{c}19^{\prime} \\
8 \text { weeks }\end{array}$ & $3 x$ & $\begin{array}{l}\downarrow \text { BMI, WHR and BMD } \\
\qquad \text { in both groups. }\end{array}$ \\
\hline Ohet al. ${ }^{50}$ & $\begin{array}{c}1-30 \mathrm{~Hz} \\
2-30-35 \mathrm{~Hz} \\
3-40 \mathrm{~Hz}\end{array}$ & $\begin{array}{l}\text { Not } \\
\text { informed }\end{array}$ & $\begin{array}{l}\text { 1-Low } \\
\text { 2-Low } \\
\text { 3-High }\end{array}$ & $\begin{array}{l}1-2 \times 30^{\prime \prime} \\
2-2 \times 30^{\prime \prime} \\
3-2 \times 1^{\prime} \\
30 " \text { rest }\end{array}$ & $\begin{array}{l}1-2 x \\
2-2 x \\
3-2 x\end{array}$ & $\begin{array}{l}\text { 1-WBV + Along. } \\
\text { 2-WBV + Ex } \\
\text { MS and Ml } \\
\text { 3-WBV + Relax. } \\
\text { Dyn. } \\
\end{array}$ & $\begin{array}{c}40^{\prime} \\
12 \text { weeks }\end{array}$ & $2 x$ & $\begin{array}{c}\downarrow \mathrm{GC}, \mathrm{PC} \text {, visceral fat, did } \\
\text { not change MM. } \uparrow \text { strength, } \\
\downarrow \text { liver fat levels, } \uparrow \text { liver } \\
\text { functions and physical } \\
\text { and mental parameters. } \\
\end{array}$ \\
\hline $\begin{array}{l}\text { Nam et } \\
\text { al. }^{51}\end{array}$ & $\begin{array}{c}16 \text { to } 34 \mathrm{~Hz} \\
\uparrow\end{array}$ & $6.8 \mathrm{~mm}$ & Not informed & $11^{\prime}$ & $3 x$ & $\begin{array}{l}\text { Est. } \\
\text { and } \\
\text { Dyn. }\end{array}$ & $\begin{array}{c}33^{\prime} \\
9 \text { months }\end{array}$ & $5 x$ & $\begin{array}{l}\downarrow S F, W C \text { and WHR, BMD } \uparrow \text { pre } \\
\text { and post only in the WBV group }\end{array}$ \\
\hline $\begin{array}{c}\text { Alvarez- } \\
\text { Alvarado } \\
\text { et al. } .^{52}\end{array}$ & $30-35 \mathrm{~Hz}$ & $\begin{array}{c}\text { Not } \\
\text { informed }\end{array}$ & Low to High & $\begin{array}{c}30-1^{\prime} \\
45-1^{\prime} \text { desc. }\end{array}$ & $2-8 x$ & Dyn. & $\begin{array}{l}11-30^{\prime} \\
6 \text { weeks }\end{array}$ & $3 x(6$ wks.) & $\begin{array}{l}\text { WBV dynamically improved } \\
\text { the systemic and aortic } \\
\text { arterial stiffness of the } \\
\text { thigh, PA, and ROP as well } \\
\text { as the strength of M.I. }\end{array}$ \\
\hline
\end{tabular}

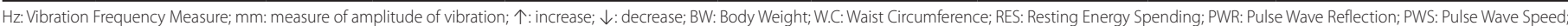
RF: Radio Frequency; BC: Body Composition;WHR:Waist-Hip Ratio; Skin Folds: SF; Muscle Mass: MM; Blood pressure: BP; Static: Est:; Dynamic: Dyn.

statically and $\mathrm{G} 2$ dynamically. The static group performed 72 seconds of vibration in 10 series, amounting to 19 minutes and 30 seconds."The dynamic group performed 10 series of 12 exercises, with a 50" second interval between series, and the same total exercise time.

Song et al. ${ }^{42}$ used WBV with a single vibration series with a time of 10 minutes twice a week. Similarly, Wilms et al..$^{44}$ used a different WBV time of 15 to 30 minutes in a single series thrice a week. Millanese et al. ${ }^{47}$ applied 14 minutes of WBV in one series but added static exercises. Each exercise lasted from 30 seconds to 1 minute, having 5 minutes of rest. The total volume of the vibration was around 19 minutes. It was performed twice a week. Belia et al. ${ }^{48}$ also used WBV only once, with 1 minute followed by a 1-minute session of rest, comprising a total of 20 seconds; the training volume was three times a week.

Vissers et al. ${ }^{41}$ began with 30 seconds and ended with 1 minute, in a six-month period. Resting time was the same for each WBV time. Total time in the first three months was 11 minutes and 9 seconds and in the last three months was 14 minutes, 2 seconds. Miyake et al. ${ }^{43}$ based the workout on a total volume of 30 minutes vibration divided by 30 seconds vibration and 30 seconds rest performed thrice a week. Similarly, Figueroa et al. ${ }^{45}$ used protocols that gradually increased in intensity, starting with 30 seconds and reaching 1 minute at the end of the research, with a volume of 10 minutes, thrice a week.

Zaki ${ }^{49}$ maintained the same vibration frequency and vibration time of 1 minute with 1-minute rest between sets but gradually increased the training volume, where it started with 3 sets reaching 10, with a training volume of three times a week. The total WBV time was near 19 minutes'. This fact was corroborated by the last 3 studies of this review, which also used protocols for gradually increasing the intensity. ${ }^{50-52}$ Regarding the vibration intensity, all started the protocols with low intensity and ended with high. The time spent in vibration varied. Oh et al..$^{50}$ used samples 
that vibrated twice a week in three series, with each series performing one type of exercise with a 30-second vibration. The first series was with the WBV in low intensity, after 30 seconds of rest, a second series started, with low vibration and the same time of 30 seconds; and the last series increased the intensity to high and the rest time to 1 minute, amounting to 40 minutes.

Nam et al..$^{51}$ were the only ones to use a WBV protocol for five days a week, with 11 minutes and 5 minutes rest time, reaching 33 minutes for each session. In addition, no one else used the largest amplitude (6.8 $\mathrm{mm}$ ), which was adjusted every three months, increasing the vibration frequency according to the body mass of each participant.

Finally, Alvarez-Alvarado et al..$^{52}$ corroborated the previous studies, drafting a protocol that increased the vibration intensity, beginning with 30 seconds and reaching 1 minute. The exercises began with 2 sets and ended with 8, with the sessions ranging from 11 minutes to 30 minutes by the end of the research. The rest period was inversely proportional.

After this review, we can observe that the WBV protocols used in obese individuals met the following criteria regarding the vibration protocols: 6 used a single vibration from beginning to end, ranging from $16 \mathrm{~Hz}$ to $35 \mathrm{~Hz}$, with $30 \mathrm{~Hz}$ prevailing. The other seven remaining studies used a gradual increase in frequency, which ranged from $16 \mathrm{~Hz}$ to $60 \mathrm{~Hz}$, with $30 \mathrm{~Hz}$ to $35 \mathrm{~Hz}$ being more predominant.

Amplitude values used ranged from $1 \mathrm{~mm}$ to $6.8 \mathrm{~mm}$, with $2 \mathrm{~mm}$ being the most used value. Seven studies did not inform what vibration intensity was used, whereas the others reposted having used an increasing intensity throughout the study, up until discharge.

The total time each individual was vibrating was at least 10 minutes and, at most, 40 minutes. Only one study used the 10-minute vibration time from beginning to the end. The others fractionated vibration with rest intervals between series. The prevailing vibration time of the others ranged from 30 seconds to 1 minute, followed by a rest interval of 30 seconds to 1 minute; but there were still 5- and 10-minute combinations.
The number of sessions most used was three times a week, highlighting the fact that three used vibration protocols once a week. In two studies, participants vibrated twice. Meanwhile, one study had a protocol of five times a week.

\section{CONCLUSION}

Regardless of the vibration protocol used, all research showed positive results when vibration was used alone or associated with other types of exercises. However, some values of these protocols were more common. The most used frequency values were $30 \mathrm{~Hz}$ and $35 \mathrm{~Hz}$. The amplitude value that was most present was $2 \mathrm{~mm}$. Most studies did not report intensity; however, those that did made gradual use of the frequency and intensity. That is, they began with smaller values and gradually increased. Regarding the time spent on the platform, most studies fractionated the total time in series, which had mean values between 30 seconds and 1 minute of vibration time, with the same values for rest. Most findings in this research used dynamic exercises associated with vibration for mostly lower limbs; although protocols performed statically also presented positive results. Finally, individuals remained vibrating for 20 to 30 minutes. The total intervention time of each study also varied widely, but the values that appeared most were 6, 8, and 12 weeks.

After analyzing the studies that comprise this review, certain aspects were selected as noteworthy for future research in this area.

- No studies found in the Portuguese language related body vibration to obese individuals, using any of the related variables, such as, age, gender, or physical, psychological, social, or ethnic characteristics.

- It is not clear what are the best protocols to use for overweight and obese people to combat this epidemic.

All authors declare no potential conflict of interest related to this article

AUTHORS' CONTRIBUTIONS: Each author made significant individual contributions to this manuscript: "Applications, results and protocols used in whole-body vibration training in obese individuals: a systematic review". Special emphasis is placed on the following roles in the creation, preparation, and final production. FATM (0000-0001-9660-5562)*: performed the systematic review, data acquisition and tabulation, and writing; GFM (0000-0003- 3551- 5963)*: contributed to the design of the experiment, analyses and writing; SLAN (00000002-7304-0527)*: contributed to the data acquisition and tabulation, and writing; RWS (0000-0003- 1445-7338)*: contributed to the data acquisition and tabulation, and revision; NMF (0000-0002-0161-4093)*: participated in the design of the experiment and revision; AAS (0000-0001-8265-6174)*: contributed to the writing and formatting of technical standards; CESF (0000-0003-2397-5866)* contributed to the final corrections. *ORCID (Open Researcher and Contributor ID).

\section{REFERENCES}

1. World Health Organization. Relatório Mundial de Saúde 2008: cuidados de saúde primários - agora mais que nunca. Geneva:WHO; 2008

2. Flegal KM, Graubard BI, Williamson DF, Gail MH. Excess deaths associated with underweight, overweight, and obesity. JAMA. 2005;293(15):1861-7.

3. Caterson ID, Gill TP. Obesity: epidemiology and possible prevention. Best Pract Res Clin Endocrinol Metab. 2002;16(4):595-610.

4. Jakicic JM. The role of physical activity in prevention and treatment of body weight gain in adults. J Nutr. 2002;132(12):3826S-9S.

5. Tsigos C, Hainer V, Basdevant A, Finer N, Fried M, Mathus-Vliegen E, et al. Management of obesity in adults: European clinical practice guidelines. Obes Facts. 2008; (2):106-16. 6.World Health Organization. Diet, Nutrition and the Prevention of Chronic Diseases. Report of a Joint WHO/FAO Expert Consultation, Geneva, 28 January - 1 February 2002. Geneva:WHO; 2002.

6. Liz $C M$, Crocetta TB, Brandt R, Andrade A. Aderência à prática de exercícios físicos em academias de ginástica. Motriz. 2010;16(1):181-8.

7. de Liz CM, Andrade A. Análise qualitativa dos motivos de adesão e desistência da musculação em academias. Rev Bras Ciênc Esporte. 2016;38(3):267-74.

8. American College of Sports Medicine. ACSM's Guidelines for Exercise Testing and Prescription. Philadelphia: Lippincott, Williams \& Wilkins; 2000

9. Rojas PNC, Nahas MV. Aderência a programas de exercícios físicos em academias de ginástica na cidade de Curitiba -PR. 2003. 112 p. Dissertação de mestrado. Universidade Federal de Santa Catarina, Centro de Desportos. Programa de Pós-Graduação em Educação Física. Florianópolis; 2003.

10. Nunomura M. Motivos de adesão à atividade física em função das variáveis idade, sexo, grau de instrução e tempo de permanência. Rev Bras Ativi Fís e Saúd. 1998;3(3):45-58.

11. Bosco C, Colli R, Introini E, Cardinale M, Tsarpela O, Mandella A, et al. Respostas adaptativas do músculo-esquelético à exposição vibratória. Clin Physiol. 1999;19(2):183-7.
12. Bosco C, lacovelli M, Tsarpela O, Cardinale M, Bonifazi M, Tihanyi J, et al. Hormonal responses to whole-body vibration in men. Eur J Appl Physiol. 2000;81(6):449-54.

13. Delecluse C, Roelants M, Verschueren S. Aumento da Força Após Vibração de Corpo Inteiro Comparado Com Treino de Resistência. Medic Scienc In Sports Exercise. 2003;195(9131/03):3506-1033.

14. Delecluse C, Roelants M, Diels R, Koninckx E, Sabinet V. Efeitos do treinamento da vibação de corpo interiro na força muscular e desempenho no sprint em atletas treinados no Sprint. Int J Sports Med. 2005;26(8):662-8

15. Da Silva ME, Núñez VM, Vaamonde D, Fernández JM, Poblador MS, García-Manso JM, et al. Effects of different frequencies of whole body vibration on muscular performance. Biol Sports. 2006;23(3):267-82

16. Mileva KN, Naleem AA, Biswas SK, Marwood S, Bowtell JL. Acute effects of a vibration-like stimulusduring knee extension exercise. Med Sci Sports Exerc. 2006;38(7):1317-28

17. Lemos TV, Pereira LM. Efeitos da plataforma vibratória no sistema musculoesquelético. Rev Movimenta 2012;5(3).

18. Rittweger J, G Beller, Felsenberg D. Acute physiological effects of exhaustive whole-body vibration exercise in man. Clin Physiol. 2000;20(2):134-42

19. Torvinen S, Kannus P, Sievanen H, Jarvinen TA, Pasanen M, Kontulainen S, et al. Effect of 8-month vertical whole body vibration on bone, muscle performance, and body balance: a randomized controlled study. J Bone Miner Res. 2003;18(5):876-84.

20. Cochrane DJ, Stannard SR. Acute whole body vibration training increases vertical jump and flexibility performance in elite female field hockey players. Br J Sports Med. 2005;39(11):860-5.

21. Ward K, Alsop C, Brown S, Caulton J, Adams J, Mughal MA. A randomized, placebo controlled, pilot trial of low magnitude high frequency loading treatment of children with disabling conditions who also have low bone mineral density. Trans Am Soc Bone Miner Res. 2001;16:S173.

22. Verschueren SM, Roelants M, Delecluse C, Swinnen S, Vanderschueren D, Boonen S. Effect of 6-month whole body vibration training on hip density, muscle strength, and postural control in postmenopausal 
women: a randomized controlled pilot study. J Bone Miner Res. 2004;19(3):352-9.

23. Guimarães JPV, Mendonça RC, Fernandes PR. Efeito da vibração mecânica na densidade óssea de mulheres menopausadas com osteoporose. Fit Perf J. 2010;9(2):57-63.

24. Von Stengel S, KemmlerW, Bebenek M, Engelke K, Kalender WA. Effects of whole-body vibration training on different devices on bone mineral density. Med Sci Sports Exerc. 2011;43(6):1071-9.

25. Maikala RV, Bhambhani YN. Functional changes in cerebral and paraspinal muscle physiology of healthy women during exposure to whole-body vibration. Accid Anal Prev. 2008;40(3):943-53.

26. Pardo EM, Alcaraz PE, Mesa F, Carrasco L. Efecto de un entrenamiento vibratorio sobre la cinemática de la glucosa, presión arterial, y dinamometría manual dinamometría manual. Arch Med Deporte. 2008;25(126):271-8

27. De Hoyo Lora M, Corrales BS, Páez LC. Respuesta cardiovascular y respiratoria aguda derivada de la aplicación de estímulos vibratorios de diferente magnitud. Apunts Med Esport. 2010;45(165):23-30.

28. Madeira JC, Rosa TD, Winkelmann ER, Bonamigo ECB. Efeito da terapia vibratória de baixa frequência em posição ortostática na doença de parkinson: Estudo de Caso. Rev Contexto Saúde. 2009;8(16):53-8.

29. Silva RG, Andreotti R, Gehring PR, Nunes MÊS, Wallerstein L, Fonseca MCO, et al. Efeito do treinamento vibratório na força muscular e em testes funcionais em idosos fisicamente ativos. Bras Cineantropom Desempenho Hum. 2009;11(2):166-73.

30. Lirani-Galvão APR, Lazaretti-Castro M. Physical approach for prevention and treatment of osteoporosis. Arq Bras Endocrinol Metab. 2010;54(2):171-8.

31. Marin RV, Oliveira ML, Rodrigues HKC, Dutra MC, Lazaretti-Castro M. Efeito de 1 ano de tratamento com plataforma vibratória de baixa intensidade melhora dor e mobilidade funcional em mulheres osteopenicas pós menopausadas. Coleção Pesquisa em Educação Física. 2012;11(3):85-92.

32. Silva PZ, Schneider RH. Efeitos da plataforma vibratória no equilíbrio de idosos. Acta Fisiatr. 2011;18(1):21-6.

33. Luo J, McNamara B, Moran K. The use of vibration training to enhance muscle strength and power. Sports Med. 2005;35(1):23-41.

34. Batista MAB, Wallerstein LF, Dias RM, Silva RG, Ugrinowitsch C, Tricoli V. Efeitos do Treinamento com Plataformas Vibratórias. Rev Bras Ci e Mov. 2007;15(3):103-13.

35. Fattorini L, Ferraresi A, Rodio A, Azzena GB, Filippi GM. Motor performance changes induced by muscle vibration. Eur J Appl Physiol. 2006;98(1):79-87.

36. Pel JJ, Bagheri J, van Dam LM, van den Berg-Emons HJ, Horemans HL, Stam HJ, et al. Platform accelerations of three different whole-body vibration devices and the transmission of vertical vibrations to the lower limbs. Med Eng Phys. 2009;31(8):937-44.

37. Batista Filho MC, Donadon LV, Duarte MLM, Galvez JM. Implementação de um sistema de controle em uma plataforma para testes de vibração de corpo inteiro (VCI). XVIII Congresso Brasileiro de Automática, Bonito-MS. 2010

38. Tovey D. Methodological Expectations of Cochrane Intervention Reviews (MECIR). Standards for the conduct and reporting of new Cochrane Intervention Reviews 2012. The Cochrane Collaboration. 2013;2.

39. Pereira MG, Galvão TF. Extração, avaliação da qualidade e síntese dos dados para revisão sistemática. Epidemiol Serv Saúde. 2014;23(3):577-8.

40. Vissers D, Baeyens JP, Truijen S, Ides K, Vercruysse CC, Van Gaal L. The effect of whole body vibration short-term exercises on respiratory gas exchange in overweight and obese women. Phys Sportsmed. 2009:37(3):88-94

41. Vissers D, Verrijken A, Mertens I, Van Gils C, Van de Sompel A, Truijen S, et al. Effect of long-term whole body vibration training on visceral adipose tissue: a preliminary report. Obes Facts. 2010;3(2):93-100.
42. Song GE, Kim K, Lee DJ, Joo NS. Whole body vibration effects on body composition in the postmenopausal korean obese women: pilot study. Korean J Fam Med. 2011;32(7):399-405.

43. Miyaki A, Maeda S, ChoiY, Akazawa N, TanabeY, So R, et al. The addition of wholebody vibration to a lifestyle modification on arterial stiffness in overweight and obese women. Artery Research. 2012;6(2):85-91.

44. Wilms B, Frick J, Ernst B, Mueller R, Wirth B, Schultes B. Whole Body Vibration Added to Endurance Training in Obese Women - A Pilot Study. Int J Sports Med. 2012;33(09):740-3.

45. Figueroa A, Gil R, Wong A, Hooshmand S, Park SY, Vicil F, et al. Whole-body vibration training reduces arterial stiffness, blood pressure and sympathovagal balance in young overweight/obese women Hypertens Res. 2012;35(6):667-72.

46. Giunta M, Cardinale M, Agosti F, Patrizi A, Compri E, Rigamonti AE, et al. Growth hormone-releasing effects of whole body vibration alone or combined with squatting plus external load in severely obese female subjects. Obes Facts. 2012;5(4):567-74

47. Milanese C, Piscitelli F, Zenti MG, Moghetti P, Sandri M, Zancanaro C. Ten-week Whole-body Vibration Training Improves Body Composition and Muscle Strength in Obese Women. Int J Med Sci. 2013;10(3):307-11

48. Bellia A, Salli M, Lombardo M, D'Adamo M, Guglielmi V, Tirabasso C, et al. Effects of whole body vibration plus diet on insulin-resistance in middle-aged obese subjects. Int J Sports Med. 2014;35(6):511-6.

49. Zaki ME. Effects of whole body vibration and resistance training on bone mineral density and anthropometry in obese postmenopausal women. J Osteoporos. 2014;2014:702589.

50. Oh S, Shida T, Sawai A, Maruyama T, Eguchi K, Isobe T, et al. Acceleration training for managing nonalcoholic fatty liver disease: a pilot study. Ther Clin Risk Manag. 2014;10:925-36.

51. Nam SS, Sunoo S, Park HY, Moon HW. The effects of long-term whole-body vibration and aerobic exercise on body composition and bone mineral density in obese middle-aged women. J Exerc Nutrition Biochem. 2016;20(2):19-27.

52. Alvarez-Alvarado S, Jaime SJ, Ormsbee MJ, Campbell JC, Post J, Pacilio J, et al. Benefits of whole-body vibration training on arterial function and muscle strength in young overweight/obese women. Hypertens Res. 2017;40(5):487-92.

53. Yoo JH, Joh HK, Do HJ, Oh SW, Lym YL, Choi JK, et al. Effects of whole body vibration exercise on body weight and body composition in young adults. Korean J Fam Med. 2009;30(2):112-9.

54. Figueroa A, Going SB, Milliken LA, Blew RM, Sharp S, Teixeira PJ, et al. Effects of exercise training and hormone replacement therapy on lean and fat mass in postmenopausal women. J Gerontol A Biol Sci Med Sci. 2003;58(3):266-70.

55. Olson TP, Dengel DR, Leon AS, Schmitz KH. Moderate resistance training and vascular health in overweight women. Med Sci Sports Exerc. 2006:38(9):1558-64.

56. Cortez-Cooper MY, Devan AE, Anton MM, Farrar RP, Beckwith KA, Todd JS, et al. Effects of high intensity resistance training on arterial stiffness and wave reflection in women. Am J Hypertens. 2005;18(7):930-4.

57. Otsuki T, Takanami Y, Aoi W, Kawai Y, Ichikawa H, Yoshika WAT. Arterial stiffness acutely decreases after whole-body vibration in humans. Acta physiologica. 2008;194(3):189-94.

58. Urbina EM, Gao Z, Khoury PR, Martin LJ, Dolan LM. Insulin resistance and arterial stiffness in healthy adolescents and young adults. Diabetologia. 2012;55(3): 625-31.

59. Chen W, Li S, Fernandez C, Sun D, Lai CC, Zhang T, et al. Temporal relationship between elevated blood pressure and arterial stiffening among middle-aged black and white adults: the Bogalusa Heart Study. Am J Epidemiol. 2016;183(7):599-608.

60. Bosy-Westphal A, Danielzik S, Dörhöfer RP, Later W, Wiese S, Müller MJ. Phase angle from bioelectrica impedance analysis: population reference values by age, sex, and body mass index. J Parenter Enteral Nutr. 2006:30(4):309-16. 